\title{
Communication technologies used by nurses in prenatal care
}

\section{Tecnologias de comunicação utilizadas por enfermeiros no pré-natal \\ Tecnologías de comunicación utilizadas por enfermeros de la atención prenatal}

\author{
Sue Helem Bezerra Cavalcante Facundo iD \\ Estácio do Ceará University Center (Centro Universitário Estácio do Ceará - ESTÁCIO/FIC) - Fortaleza (CE) - Brazil
}

Raimunda Magalhães da Silva (iD

University of Fortaleza (Universidade de Fortaleza - UNIFOR) - Fortaleza (CE) - Brazil

Jonas Loiola Gonçalves

University of Fortaleza (Universidade de Fortaleza - UNIFOR) - Fortaleza (CE) - Brazil

Fernanda Colares de Borba Netto iD

University of Fortaleza (Universidade de Fortaleza - UNIFOR) - Fortaleza (CE) - Brazil

Maria Veraci Oliveira Queiroz ID
Ceará State University (Universidade Estadual do Ceará - UECE) - Fortaleza (CE) - Brazil

Christina César Praça Brasil iD

University of Fortaleza (Universidade de Fortaleza - UNIFOR) - Fortaleza (CE) - Brazil

\begin{abstract}
Objective: The study aimed to identify the communication technologies used by prenatal nurses in Primary Health Care. Methods: This descriptive cross-sectional study was conducted with 97 nurses in 27 Primary Health Care Centers of Fortaleza, Ceará, Brazil. Data were collected from July to November 2016 through an author-developed questionnaire addressing sociodemographic issues and educational and communication technologies. Inclusion criteria were prenatal nurses with at least an eight-month experience and three months on the current job. Data were analyzed using the Statistical Package for the Social Sciences, version 20.0. Results: Admission of pregnant women was not performed by $50.5 \%$ (49) of the nurses. Most nurses $70.5 \%$ (68) did not receive training on technology use and $81.4 \%$ (79) used SISPRENATAL. In all, 94.8\% (92) of the participants used the electronic medical record and the prenatal record card. Conclusion: The main technologies used for monitoring pregnancy progress were the electronic medical record and the prenatal record card. There is notably a lack of training on technology for nurses.
\end{abstract}

Descriptors: Technology; Health Communication; Nursing; Prenatal Care; Primary Health Care.

\section{RESUMO}

Objetivo: O estudo objetivou identificar as tecnologias de comunicação utilizadas por enfermeiros no pré-natal na Atenção Primária à Saúde. Métodos: Estudo descritivo e de corte transversal realizado com 97 enfermeiros em 27 Centros de Atenção Primária à Saúde de Fortaleza, Ceará, Brasil. Os dados foram coletados de julho a novembro de 2016, por meio de um questionário elaborado pelos próprios pesquisadores, composto por questões sociodemógráficas e sobre tecnologias educacionais e comunicacionais. Os critérios de inclusão compreenderam enfermeiros executores do pré-natal, com experiência mínima de oito meses e há pelo menos três meses no serviço. Os dados foram analisados com programa Statistical Package for the Social Sciences, versão 20.0. Resultados: A admissão de gestantes não foi realizada por 50,5\% (49) dos enfermeiros. A maioria dos enfermeiros (70,5\%; 68) não recebeu treinamento para o uso das tecnologias e $81,4 \%$ (79) utilizavam o SISPRENATAL. No total, 94,8\% (92) dos participantes utilizaram o prontuário eletrônico e o cartão de pré-natal na sua prática. Conclusão: As principais tecnologias apontadas para monitorar o progresso da gravidez foram o prontuário eletrônico e o cartão de pré-natal. Destacando-se a falta de treinamento para os enfermeiros em tecnologias.

Descritores: Tecnologia; Comunicação em Saúde; Enfermagem; Cuidado Pré-Natal; Atenção Primária à Saúde.

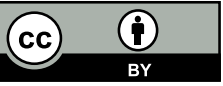




\section{RESUMEN}

Objetivo: El objetivo del estudio ha sido identificar las tecnologías de comunicación utilizadas en el prenatal por enfermeros de la Atención Primaria de Salud. Métodos: Estudio descriptivo y de corte transversal realizado con 97 enfermeros de 27 Centros de Atención Primaria de Salud de Fortaleza, Ceará, Brasil. Se ha recogido los datos entre julio y noviembre de 2016 a través de un cuestionario elaborado por los propios investigadores con preguntas sociodemográficas y sobre las tecnologías educacionales y de comunicación. Los criterios de inclusión fueron enfermeros que trabajaban con prenatal, los que tenían experiencia mínima de ocho meses y por lo menos tres meses en el servicio. Se analizaron los datos con el programa Statistical Package for the Social Sciences, versión 20.0. Resultados: La admisión de embarazadas no ha sido realizada por el 50,5\% (49) de los enfermeros. La mayoría de los enfermeros $(70,5 \% ; 68)$ no ha sido entrenado para el uso de las tecnologías y el $81,4 \%$ (79) utilizaban el SISPRENATAL. En el total, el 94,8\% (92) de los participantes utilizaron el historial electrónico y la tarjeta de prenatal en su práctica. Conclusión: Las principales tecnologías señaladas para el monitoreo del progreso del embarazo han sido el historial electrónico y la tarjeta de prenatal. Se destaca la ausencia de entrenamiento sobre tecnologías para los enfermeros.

Descriptores: Tecnología; Comunicación en Salud; Enfermería; Atención Prenatal; Atención Primaria de Salud.

\section{INTRODUCTION}

Prenatal care actions and technologies together favor the quality of care. However, they do not ensure quality due to the uncertainty of their use ${ }^{(1)}$. In addition, the non-systematized inclusion and/or the inappropriate use of these technologies generate risks to users and undermine the effectiveness of the health system ${ }^{(2)}$.

The type of care needed determines which technologies should be used ${ }^{(3)}$. Therefore, the idea that technology involves, in addition to devices, the way in which knowledge is used to carry out actions and activities should be reinforced. Thus, a health technology is any intervention that may be used to promote health ${ }^{(4)}$.

The presence of specific nursing technologies should be highlighted. Communication process technologies are mechanisms employed by professionals to act as mediators of therapeutic proposals or information provision, that is, mediators of the various forms in which professionals and patients relate ${ }^{(5)}$.

In June 2000, Brazil's Ministry of Health (MoH) implemented the Prenatal Care and Birth Humanization Program (Programa de Humanização do Pré-Natal e Nascimento - PHPN) and standardized care actions that should be carried out during pregnancy and postpartum ${ }^{(6)}$. The initiative provides care to women during reproductive planning and advocates for the humanization of pregnancy, childbirth and postpartum care, thereby ensuring the children's rights to be born free from diseases and to have a healthy growth and development ${ }^{(7)}$.

The MoH Stork Network puts the women at the heart of the care process and ensures a safe pregnancy, childbirth and postpartum period. The official documents that regulate the Stork Network indicate the key agents and their roles, objectives, actions, goals, resources and indicators ${ }^{(8)}$.

According to the Prenatal Care Guidelines and the basic actions recommended by the $\mathrm{MoH}$, the following communication process technologies should be considered: pregnant woman's admission, pregnant woman's brochure, SISPRENATAL (a software used in Brazil for the recording of information about pregnant women and the monitoring and evaluation of prenatal and postpartum care), medical record, daily record book, protocols and means used for patient referral and educational actions ${ }^{(9)}$.

The communication technologies form bridges between information related to pregnancy and pregnant women and between health professionals and the population. A study conducted in Pakistan revealed the participation of Pakistani women in the activities of an Information and Communication Center that gave them access to healthrelated information through online and offline resources ${ }^{(10)}$.

Studies show that the use of new technologies in the communication process is efficient and assist in the health care of pregnant women. However, little is known about which communication technologies are used and how they can assist in the provision of prenatal care in primary health care services ${ }^{(11-15)}$.

The need for improvements in care and the reduction of inequalities in prenatal care is necessary for the consolidation of viable technologies for health promotion to identify limitations and enhance their adaptation to services. This cross-cutting approach to the use of technologies in prenatal care in the search for more problemsolving actions is one of the principles supported by the National Health Promotion Policy as it contributes to the development of actions that may respond to social health needs ${ }^{(1,4,16)}$

In view of the considerations outlined above, the present study is relevant as it may contribute to the construction of knowledge on the subject and the development of more technologies. In addition, it may contribute to the improvement of technologies that already exist and improve the quality of care and management practice. 
Thus, the present study aimed to identify the communication technologies used by prenatal nurses in Primary Health Care.

\section{METHODS}

This descriptive cross-sectional study was carried out in 27 Primary Health Care (PHC) centers located in the Administrative Region 6 of Fortaleza, Ceará, Brazil. This region has an estimated population of 600,000 inhabitants distributed in 29 neighborhoods that correspond to $42 \%$ of the territory of Fortaleza. The region has the largest amount of health services (27) in the city ${ }^{(17)}$.

The estimated sample size was 102 nurses from a total of 138 nurses who work in the PHC centers. The final sample consisted of 97 nurses who met the inclusion criteria. The sample was determined based on the prevalence $(P)$ of nurses $(50 \%)$ who use several technologies and a sampling error of $5 \%$.

In order to be included in the study, nurses should provide prenatal care and have at least an eight-month experience in prenatal care and three months working in the PHC center. Nurses with such experience are thought to have enough knowledge about the use of the technologies available in the service.

Data were collected from July to November 2016 using an author-developed questionnaire with 16 questions about the sociodemographic characterization of the participants (sex, marital status, religion, training, type of employment, and use of technologies), main technologies used by nurses in prenatal care and recommended technology structures to improve care (age, number of children, length of employment in the PHC center, weekly working hours in the PHC center, length of employment in profession, number of pregnant women registered in the PHC center, and number of pregnant women served by Community Health Workers - CHW).

The data were entered, organized and processed in the Statistical Package for the Social Sciences (SPSS) version 20.0 and are presented in tables. The quantitative data were complemented with nurses' accounts of the relationship between technology use and quality of prenatal care.

The data were analyzed descriptively using absolute and relative frequencies for categorical variables and mean and standard deviation for numerical variables. We estimated the prevalence of use of the following forms of communication technology for the delivery of prenatal care by nurses in the PHC centers from patient admission to follow-up: medical records, prenatal record card, educational material, daily record book, and SISPRENATAL.

Frequencies of the technologies used in educational activities and in decision making regarding pregnant women's care were also described. Some questions in the questionnaire allowed more than one response. In addition, some questions were left unanswered. Therefore, some items presented values that did not match the sample size.

Differences in sex, age, academic degree, length of employment in profession, length of employment in the PHC center and type of employment between the nurses who used the technologies and those who did not were estimated.

Differences between the categorical variables were estimated using Fisher's Exact Test. Numerical variables were tested for normality using the Kolmogorov-Smirnov Test. Comparisons involving non-normal numerical variables (age $p=0.002$; length of employment in profession $p<0.001$ ) were performed using the Mann-Whitney $U$ Test. The significance level was set at $5 \%$ in all analyses.

All the procedures performed in the present study involving human participants were in accordance with the ethical standards of the national research committee and with the 1964 Helsinki declaration and its later amendments or comparable ethical standards. Informed consent was obtained from all individual participants included in the study. The present research complies with the ethical precepts of Resolution 466/12 of the National Health Council(18) and was approved by the Research Ethics Committee (n.1.584.117).

\section{RESULTS}

Most of the nurses $(n=91 ; 93.8 \%)$ involved in the present study were women. The participants were predominantly aged $36-45$ years $(62.9 \% ; n=61)$, with a mean age of $41.7 \pm 8.3$ years.

Most of the participants were married $(68 \% ; n=66)$ and had a mean of $1.4 \pm 1$ children. The mean length of employment in profession was $15.7 \pm 7.4$ years. A little more than half of the nurses had a graduate degree $(55 \%$; $\mathrm{n}=53)$ and $22(22 \% ; n=21)$ had an undergraduate degree.

About the type of employment, most of the participants $(84.5 \% ; n=82)$ were civil servants. The mean length of employment in the PHC center was $7.6 \pm 6.6$ years and the mean weekly working hours were $36 \pm 5.3$ hours. The nurses served a mean of $23.6 \pm 12.2$ pregnant women and only $17.9 \pm 10.4$ pregnant women were served by CHW.

In all, $68(70.1 \%)$ nurses reported not having received any training to operate the technologies used in prenatal care. Of the $27.8 \%(n=27)$ of the nurses who received training, $37 \%(n=36)$ received electronic medical records training and $18.5 \%(n=18)$ received SISPRENATAL training. 
Information about pregnant women were entered into SISPRENATAL database by $79(81.4 \%)$ nurses and the others reported having difficulty entering the information. Admission of pregnant women as recommended by the Ministry of Health was not carried out by $49(50.5 \%)$ nurses.

In all, $92(94.8 \%)$ nurses used both the electronic medical record and the prenatal record card to record the actions and activities carried out during pregnancy care (Table I).

The electronic medical record $(93.8 \% ; n=91)$ and the prenatal record card $(96.9 \% ; n=94)$ were the main technologies used by nurses to monitor the progress of pregnancy during prenatal care (Table I).

Pregnant women's absences from scheduled appointments were recorded by 58 (59.8\%) nurses on the electronic medical record. In addition, 32 (33\%) nurses created a daily record book to facilitate access to information and $26.8 \%$ $(n=26)$ identified absences using information provided by CHW (Table I).

When there was a clinical need to refer the pregnant woman to another professional in the same center, nurses used a standardized form $(54.6 \% ; n=53)$ in the electronic medical record or even a prescription pad $(47 \% ; n=45)$; however, $74(76.3 \%)$ nurses reported they never received counter-referral information.

As for other technologies used in educational activities, 47 (48.5\%) nurses reported using information booklets, $43(44.3 \%)$ used pamphlets and 27 (27.8\%) used videos. These technologies were provided by the Ministry of Health.

Regarding the technologies used for clinical decision making, 87 (89.7\%) nurses reported using institutional protocols, $80(82.5 \%)$ used manuals developed by the Ministry of Health and $51(52.6 \%)$ used information from books (Table I).

Table I - Technologies used by nurses in prenatal care, Fortaleza, Ceará, Brazil, 2016. ( $n=97)$

\begin{tabular}{|c|c|c|}
\hline Variables with multiple responses & $\mathbf{n}$ & $\%$ \\
\hline \multicolumn{3}{|l|}{ Technologies used to register the pregnant woman } \\
\hline Electronic SISPRENATAL & 79 & 81.4 \\
\hline Print registration form for further registration at SISPRENATAL & 18 & 18.6 \\
\hline Electronic or paper-based medical record & 27 & 27.8 \\
\hline Other & 7 & 7.2 \\
\hline \multicolumn{3}{|c|}{ Technologies used to monitor the progress of pregnancy during prenatal care } \\
\hline SISPRENATAL & 33 & 34.0 \\
\hline Electronic or paper-based medical record & 91 & 93.8 \\
\hline Prenatal care record & 94 & 96.9 \\
\hline Daily record book & 15 & 15.5 \\
\hline \multicolumn{3}{|c|}{ Technologies used to record information and monitor pregnant women } \\
\hline SISPRENATAL & 28 & 28.9 \\
\hline Electronic medical record & 92 & 94.8 \\
\hline Prenatal care record & 92 & 94.8 \\
\hline Daily record book & 26 & 26.8 \\
\hline \multicolumn{3}{|l|}{ Technology used to identify absent pregnant women } \\
\hline Daily record book & 32 & 33.0 \\
\hline Medical record & 58 & 59.8 \\
\hline $\mathrm{CHW}$ & 26 & 26.8 \\
\hline Professionals' planners & 10 & 10.3 \\
\hline \multicolumn{3}{|l|}{ Technologies used in educational activities } \\
\hline Videos & 27 & 27.8 \\
\hline Multimedia projector & 14 & 14.4 \\
\hline Pamphlets & 43 & 44.3 \\
\hline Informative booklet & 47 & 48.5 \\
\hline Other & 40 & 41.2 \\
\hline \multicolumn{3}{|c|}{ Technologies used to support clinical decision making in pregnant women's care } \\
\hline Books & 51 & 52.6 \\
\hline Scientific articles & 27 & 27.8 \\
\hline Manuals & 80 & 82.5 \\
\hline Protocols & 87 & 89.7 \\
\hline Other & 20 & 20.6 \\
\hline
\end{tabular}

CHW: Community Health Workers 
There was a statistically significant relationship between the use of games in educational activities and the age of the nurses $(p=0.021)$. The nurses who used games had a lower mean age $(33.8 \pm 4.7)$ compared with the others $(42.0 \pm 8.2)$.

There was also a statistically significant relationship between the use of applications in educational activities and the age of the nurses $(p=0.015)$. The nurses who used applications had a lower mean age (31.3 \pm 7.2$)$ compared with the others $(42.0 \pm 8.1)$ (Table II).

When asked about the non-use of any technology, 38.1\% $(n=36)$ of the nurses said this had never happened; however, $13.4 \%(n=12)$ of the participants said they no longer conducted groups of pregnant women due to shortage of time - as they have to carry out patient admission activities - and the lack of motivation by the managers.

There was also a statistically significant relationship between use of scientific articles to support clinical decision making and the sex of the nurses $(p=0.049)$. The prevalence of the use of scientific articles was higher among men $(\mathrm{n}=4 ; 66.7 \%)$ (Table II).

Similarly, the use of applications to support clinical decision making was statistically associated with the sex of the nurses $(p=0.043)$. The prevalence of the use of applications was higher among men $(n=2 ; 33.3 \%)$ (Table II).

It should be noted that the perinatal record was not used as it had been replaced by the electronic medical record in almost all the PHC centers. Only one annex building of one of the centers did not have a computer and therefore used paper-based records. It was not possible to estimate how many nurses held educational meetings and their periodicity.

The nurses were asked about the correlations between the use of technologies in the communication process and the quality of prenatal care. In all, $11(11.3 \%)$ nurses did not state their point of view.

The nurses were asked to recommend communication technologies that could improve the quality of prenatal care. In all, 67 (69\%) nurses recommended some technology, such as groups of pregnant women $13(14.4 \%)$ and electronic records $12(13.4 \%)$. It should be noted, however, that $27(27.8 \%)$ nurses did not recommend any technology.

Table II - Use of games and applications in educational activities according to the age of the nurses, Fortaleza, Ceará, Brazil, 2016.

\begin{tabular}{ccccc}
\hline Games & N & Mean Age & Standard Deviation & p-value \\
\hline Yes & 4 & 33.8 & 4.7 & $\mathbf{0 . 0 2 1}$ \\
No & 93 & 42.0 & 8.2 & p-value \\
\hline Application & $\mathbf{N}$ & Mean Age & Standard Deviation & $\mathbf{0 . 0 1 5}$ \\
\hline Yes & 3 & 31.3 & 7.2 & \\
No & 94 & 42.0 & 8.1 & \\
\hline
\end{tabular}

Source: Mann-Whitney U Test

\section{DISCUSSION}

The results revealed that the technologies most used by nurses in prenatal care were the electronic medical record and the prenatal record card. Referral to reference services was performed using standardized forms and many nurses did not receive information about the pregnant woman's counter-referral.

During educational activities nurses used booklets, pamphlets and videos. With regard to clinical decision making, they reported using institutional protocols and manuals from the Ministry of Health.

Many pregnant women were left unserved by $\mathrm{CHW}$, which hindered adherence to prenatal care. A study carried out in Southern Brazil showed that pregnant women who received home visits by community health workers started prenatal care at the beginning of pregnancy, attended a larger number of consultations and took more routine complementary exams ${ }^{(19)}$.

The SISPRENATAL is a software used in Brazil for the recording of information on pregnant women and the monitoring and evaluation of prenatal and postpartum care provided by health services to pregnant women and newborns from the first consultation in the PHC center to in-hospital high risk care. The software also helps identify elements that characterize a high-risk pregnancy and assists in the recognition of complications that contribute to maternal and perinatal morbidity and mortality ${ }^{(20)}$. 
The SISPRENATAL and the medical record contain specific and important information that should be recorded regularly during pregnancy. The information recorded on the medical record allow practical comparisons between one consultation and another, thus favoring a rapid analysis of the progress of pregnancy ${ }^{(21)}$.

The electronic medical record implemented in the city has some problems. According to the nurses, the system is time-consuming and depends on internet connection to work. In addition, it does not allow the identification of pregnant women who miss scheduled appointments. In view of these problems, some nurses have developed their own technologies to record information on pregnant women's care.

The admission of pregnant women to Primary Health Care centers should involve careful listening. Professionals should carefully listen to pregnant women's questions, anxieties and complaints to assess their vulnerabilities and tailor the care based on their needs ${ }^{(10)}$.

Another important issue that deserves attention is that both referral and counter-referral of pregnant women are not standardized. The non-standardization of written communication in these processes can lead to mix-ups, confusion or even information gaps. Similarly, information on referrals to specialized care are recorded on both standardized records $(59.8 \%)$ and prescription pads $(38.1 \%)$, i.e., there is no standardization of the technologies used in this process.

The lack of technology standardization may be one of the factors that lead to a low rate of counter-referral of pregnant women and reveals a gap in interprofessional communication. Pregnant women referred to secondary health care services for high-risk care, for example, are brought there and do not return to primary health care. This situation hinders the continuity of primary care - it is known that, in addition to specialized care, pregnant women need primary care, especially in the postpartum period. Some professionals who were aware of this problem said they invited pregnant women to continue attending consultations in the PHC centers. Furthermore, they reported obtaining information about the consultations that took place in secondary health care services from the patients themselves.

A study carried out in a secondary and tertiary health care center located in Southeastern Brazil found that problems related to counter-referral were mainly due to excess demand, lack of time, lack of communication, lack of medium-complexity care services in the region, among other problems. It should be noted that most of these problems are managerial problems and that the disorganization of care hinders pregnant women's comprehensive care ${ }^{(22)}$.

Despite the availability of several communication technologies, many nurses still do not have access to them. Investing in technology favors the provision of efficient and effective quality services, thus contributing to the improvement of care ${ }^{(3)}$.

These recent actions, added to those previously implemented in prenatal care, present new challenges for health care teams and managers. Therefore, health professionals will increasingly need to use health technologies, which are relevant means for improving the health care of pregnant women and reducing health $\operatorname{costs}^{(2)}$.

In a study of educational technologies used in the provision of prenatal care in Northeastern Brazil, a group of nurses conducted a game called "Maternal Knowledge Wheel" with 17 pregnant women attending two PHC centers. The game consisted of colored envelopes with questions and answers about labor, immediate postpartum period and breast care. Each correct answer was assigned a score, and for each wrong answer the participant should perform a given task. When wrong answers were given, the participants should roll a big dice that contained pictures indicating the task they should perform. The tasks were related to newborn care. The participants should simulate care using dolls, cribs, bathtubs, and other items ${ }^{(23)}$.

The game aimed to improve pregnant women's knowledge about pregnancy, delivery, postpartum period and newborn care. It contributed to the clarification of questions and experience sharing during prenatal care and improved nurses' knowledge about the pregnant women they served. Educational games have been proven to facilitate nursing practice. These technologies have been effective in clarifying the main doubts of pregnant teenagers and encouraging breastfeeding(24).

A study carried out in PHC centers in Northeastern Brazil to assess pregnant women's and nurses' prenatalrelated knowledge revealed difficulties in the provision of prenatal care and misconceptions about care quality and satisfaction/dissatisfaction with the service provided ${ }^{(25)}$.

According to the participants of the study, careful listening, use of technological resources, comprehensive care and nurses' attendance at consultations represented a quality prenatal care.

The most common technologies used by the nurses analyzed in the present study were information booklets $(48.5 \%)$ and pamphlets (44.3\%). It should be noted that these technologies were mostly used by the nurses aged over 31 years and those who have been working as nurses for more than three years. This finding demonstrates nurses' need to invest more in new technologies for the delivery and management of prenatal care. 
The main technologies used to support clinical decision making in pregnant women's care were manuals (82.5\%) and protocols $(89.7 \%)$ developed by the Ministry of Health and/or the Municipal Health Secretariat. A few nurses $(27.8 \%)$ used scientific articles to support clinical decision making. Most of the nurses did not keep themselves updated with the latest evidence-based studies and just a few adhered to technologies available in websites and applications - even though they had access to computers and personal smartphones with internet connection. It should be noted that scientific articles published in journals can disseminate current information on health issues ${ }^{(26)}$.

When asked about the correlation between the use of communication technologies and prenatal care quality, some of the nurses participating in the present study said that these technologies can improve pregnant women's knowledge about pregnancy. As a result, pregnant women get more interested in adhering to prenatal care and feel responsible for their self-care.

The importance of providing health education through group activities to promote comprehensive care should be highlighted. However, there is a need for re-evaluating the methodologies and practices used in groups of pregnant women $^{(27)}$.

A randomized clinical trial conducted between 2006 and 2008 examined the use of an audiovisual resource (Video Doctor Plus) to provide information to 410 pregnant smokers attending community-based prenatal clinics in the San Francisco Bay Area. Intervention participants $(n=42)$ received 15-minute Video Doctor sessions for one month. The intervention produced a significant decrease in the number of days smoked and in cigarettes smoked per day. Technology was an efficacious adjunct to routine prenatal care as it promoted smoking reduction among pregnant smokers ${ }^{(28)}$.

Thus, technology is an indispensable resource to improve prenatal care quantitively and qualitatively ${ }^{(23)}$. Furthermore, public health nurses could adhere to and improve the use of specific interventions using social media ${ }^{(16,29-31)}$.

The fact that it was not possible to investigate how technology is used in nurses' daily practice constitutes a limitation of the present study. However, assessing the use of technology in prenatal care may help understand the processes of communication between pregnant women and health professionals and their impact on the quality of prenatal care. Technology contributes to the improvement of health care and the fulfillment of fundamental rights through disease prevention and health promotion actions.

In order to improve the capacity to solve prenatal care-related problems in Primary Health Care (PHC) and women's adherence to prenatal care, health professionals should know and use health technologies and researchers should constantly evaluate the impacts of these technologies within this context.

\section{CONCLUSION}

The technologies most used by prenatal nurses were the electronic medical record and the prenatal record card. The nurses in the present study said that the Community Health Workers (CHW) also played an important role in the communication with pregnant women as they were closer to them and thus could intensify the provision of health care guidelines.

It should also be noted that just a few forms of technology were used to optimize the communication between nurses and pregnant women, between health professionals, and between other health professionals and pregnant women.

\section{CONFLICTS OF INTEREST}

The authors declare that there is no conflict of interest regarding this study.

\section{CONTRIBUTIONS}

Sue Helem Bezerra Cavalcante Facundo and Raimunda Magalhães da Silva contributed to the study conception and design, acquisition, analysis and interpretation of data and writing of the manuscript. Jonas Loiola Gonçalves contributed to the acquisition of data and writing and revision of the manuscript. Fernanda Colares de Borba Netto, Maria Veraci Oliveira Queiroz and Christina César Praça Brasil contributed to the writing and revision of the manuscript.

\section{REFERENCES}

1. Gonçalves MF, Teixeira EMB, Silva MAS, Corsi NM, Ferrari RAP, Pelloso SM, et al. Pré-natal: preparo para o parto na atenção primária à saúde no sul do Brasil. Rev Gaúcha Enferm [Internet]. 2017 [accessed on 
2019 Dec 05];38(3):e0063. Available from: http://www.scielo.br/scielo.php?script=sci_arttext\&pid=S198314472017000300401\&lng=pt doi: 10.1590/1983-1447.2017.03.2016-0063

2. Ministério da Saúde (BR), Comissão Nacional de Incorporação de Tecnologias no SUS. Diretriz Nacional de Assistência ao Parto Normal [Internet]. Brasília: Ministério da Saúde; 2016 [accessed on 2019 Dec 05]. Available from: http://conitec.gov.br/images/Consultas/2016/Relatorio_Diretriz-PartoNormal_CP.pdf

3. Del Angelo AN, Dias DMV, Fonseca LMM, Campbell SH, Martins JCA, Rodrigues MA. E-baby skin integrity: evidence-based technology innovation for teaching in neonatal nursing. Esc Anna Nery [Internet]. 2018 [accessed on 2019 Dec 05];22(3):e20170424. Available from: http://www.scielo.br/scielo.php?script=sci_ arttext\&pid=S1414-81452018000300211\&Ing=en. doi: 10.1590/2177-9465-ean-2017-0424

4. Mathes T, Antoine SL, Prengel P, Bühn S, Polus S, Pieper D. Health technology assessment of public health interventions: a synthesis of methodological guidance. Int J Technol Assess Health Care. 2017;33(2):135-46.

5. Abreu TFK, Amendola F, Trovo MM. Tecnologias relacionais como instrumentos para o cuidado na Estratégia Saúde da Família. Rev Bras Enferm [Internet]. 2017 [accessed on 2019 Dec 05];70(5):981-7. Available from: http://www.scielo.br/scielo.php?script=sci_arttext\&pid=S0034-1672017000500981\&lng=pt doi: 10.1590/00347167-2016-0337

6. Ministério da Saúde (BR). Portaria GM/MS n.569, de 01 de junho de 2000. Institui o Programa de Humanização no Pré-natal e Nascimento no âmbito do Sistema Único de Saúde. [Brasília]: Ministério da Saúde Diário Oficial da União; 2000.

7. Leal MC. Avanços na assistência ao parto no Brasil: resultados preliminares de dois estudos avaliativos. Cad Saúde Pública [Internet]. 2019 [accessed on 2019 Dec 06];35(7):e00223018. doi: 10.1590/0102$311 \times 00223018$

8. Leal MC. Parto e nascimento no Brasil: um cenário em processo de mudança. Cad Saúde Pública [Internet]. 2018 [accessed on 2019 Dec 06];34(5):e00063818. doi: 10.1590/0102-311X00063818

9. Ministério da Saúde (BR), Secretaria de Atenção à Saúde, Departamento de Atenção Básica. Atenção ao prénatal de baixo risco. Brasília: Ministério da Saúde; 2012.

10. Zakar R, Zakar MZ, Qureshi S, Fischer F. Harnessing information technology to improve women's health information: evidence from Pakistan. BMC Womens Health. 2014;14:105.

11. Matta-Machado AT, Lima ÂMLD, Abreu DMX, Araújo LL, Fonseca D Sobrinho, Lopes EAS, et al. Is the use of information and communication technology associated with aspects of women's primary health care in Brazil? J Ambul Care Manage [Internet]. 2017 [accessed on 2019 Dec 06];40(2 Suppl):S49-S59. doi:10.1097/ JAC. 0000000000000187

12. Chilukuri N, West M, Henderson JL, Lawson S, Ehsanipoor R, Costigan K, et al. Information and communication technology use among low-income pregnant and postpartum women by race and ethnicity: a cross-sectional study. J Med Internet Res [Internet]. 2015 [accessed on 2019 Dec 06];17(7):e163. Available from: https://www.jmir.org/2015/7/e163 doi: 10.2196/jmir.3916

13. Vamos CA, Green SM, Griner S, Daley E, DeBate R, Jacobs T, et al. Identifying Implementation Science Characteristics for a Prenatal Oral Health EHealth Application. Health Promot Pract [Internet]. 2020 [accessed on 2019 Dec 06];21(2):246-58. doi: 10.1177/1524839918793628

14. Haddad SM, Souza RT, Cecatti JG. Mobile technology in health (mHealth) and antenatal care-Searching for apps and available solutions: A systematic review. Int J Med Inform. 2019;127:1-8.

15. Bangal V, Somasundaram KV, Thitame S. Influence of mobile communication on utilization and outcome of maternal health services in rural area. Indian J Public Health Res Dev. 2018;5(9).

16. Ministério da Saúde (BR). Política Nacional de Promoção da Saúde: PNPS: Anexo I da Portaria de Consolidação $n^{\circ} 2$, de 28 de setembro de 2017 , que consolida as normas sobre as políticas nacionais de saúde do SUS. Brasília: Ministério da Saúde; 2018.

17. Prefeitura Municipal de Fortaleza. Postos de saúde [Internet]. Fortaleza: PMF; 2016 [accessed on 2016 Nov 28]. Available from: https://catalogodeservicos.fortaleza.ce.gov.br/categoria/saude/servico/65

18. Ministério da Saúde (BR), Conselho Nacional de Saúde. Resolução nº 466, de 12 de dezembro de 2012. 
Diretrizes e normas regulamentadoras de pesquisas envolvendo seres humanos. Brasília: CNS; 2013.

19. Cesar JA, Mendoza-Sassi RA, Ulmi EF, Dall'agnol MM, Neumann NA. Diferentes estratégias de visita domiciliar e seus efeitos sobre a assistência pré-natal no extremo Sul do Brasil. Cad Saúde Pública. 2008;24:2614-22.

20. Ministério da Saúde (BR). SIS Pré-Natal [Internet]. Brasília: DATASUS; 2014 [accessed on 2016 Dec 10]. Available from: http://www.datasus.gov.br/SISPRENATAL/index.php?area=01

21. Luz LA, Aquino R, Medina MG. Avaliação da qualidade da Atenção Pré-Natal no Brasil. Saúde Debate [Internet]. 2018 [accessed on 2019 Dec 12];42(spe2):111-26. doi: 10.1590/0103-11042018S208

22. Menozzi K. O sistema de referência e contrarreferência no contexto da equipe multiprofissional de saúde [thesis]. Botucatu: Universidade Estadual Paulista; 2013.

23. Alves ACP, Figueiredo MFER, Sousa NPL, Oliveira CJ, Oliveira DR, Sousa WM. Aplicação de tecnologia leve no pré-natal: um enfoque na percepção das gestantes. Rev Enferm UERJ. 2013;21:648-53.

24. Silva AKC, Oliveira KMM, Coelho MMF, Moura DJM, Miranda KCL. Development and validation of an educational game for adolescents about breastfeeding. Rev Baiana Enferm. 2017;31:16476.

25. Guerreiro EM, Rodrigues DP, Queiroz ABA, Ferreira MA. Educação em saúde no ciclo gravídico-puerperal: sentidos atribuídos por puérperas. Rev Bras Enferm. 2014;67:13-21.

26. Packer AL, Tardelli AO, Castro RCF. A distribuição do conhecimento científico público em informação, comunicação e informática em saúde indexado nas bases de dados MEDLINE e LILACS. Cienc Saúde Colet. 2007;12:587-99.

27. Pio DAM, Oliveira MM. Educação em saúde para atenção à gestante: paralelo de experiências entre Brasil e Portugal. Saúde Soc. 2014;23:313-24.

28. Tsoh JY, Kohn MA, Gerbert B. Promoting smoking cessation in pregnancy with Video Doctor plus provider cueing: a randomized trial. Acta Obstet Gynecol. 2010;89:515-23.

29. Keim-Malpass J, Mitchell EM, Sun E, Kennedy C. Using Twitter to Understand Public Perceptions Regarding the \#HPV Vaccine: Opportunities for Public Health Nurses to Engage in Social Marketing. Public Health Nurs. 2017;34:316-23.

30. Santos ALM, Souza MHT. Elaboração de novas tecnologias em enfermagem: utilização de uma cartilha para prevenção. Rev Enferm UFPE. 2017;11(10):3893-98.

31. Jorge HMF, Hipólito MCV, Masson VA, Silva RM. Assistência pré-natal e políticas públicas de saúde da mulher: revisão integrativa. Rev Bras Promoç Saúde. 2015;28(1):140-8.

\section{First author's address:}

Sue Helem Bezerra Cavalcante Facundo

Centro Universitário Estácio do Ceará

Rua Eliseu Uchoa Becco, 600

Bairro: Patriolino Ribeiro

CEP: 60.810-270 - Fortaleza - CE - Brasil

E-mail: susuhelem@hotmail.com

\section{Mailing address:}

Raimunda Magalhães da Silva

Universidade de Fortaleza - UNIFOR

Programa de Pós-Graduação em Saúde Coletiva

Av. Washington Soares, 1321/ Bloco B

Bairro: Edson Queiroz

CEP: 60.811-905 - Fortaleza - CE - Brasil

E-mail: rmsilva@unifor.br

How to cite: Facundo SBHC, Silva RM, Gonçalves JL, Netto FCB, Queiroz MVO, Brasil CCP. Communication technologies used by nurses in prenatal care. Rev Bras Promoç Saúde. 2020;33:9882. 